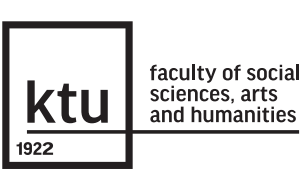

SAL 38/2021

Research Journal Studies about Languages pp. $61-80$

ISSN 1648-2824 (print) ISSN 2029-7203 (online) DOI 10.5755/j01.sal.138.27519
LINGUISTICS / KALBOTYRA

Конвербы в русском и литовском языках
Accepted 02/2021

crossef http://dx.doi.org/10.5755/j01.sal.1.38.27519
HOW TO CITE: Lichačiova, A., \& Burbienè, D. (2021). Конвербы в русском и литовском языках. Studies about Languages / Kalbų studijos, 38, 61-80. http:// doi.org/10.5755/j01.sal.1.38.27519

\title{
Конвербы в русском и литовском языках
}

\author{
Konverbai rusų ir lietuvių kalbose
}

ДИАНА БУРБЕНЕ, Вильнюсский университет, Каунасский технологический университет, Литва

АЛЛА ЛИХАЧЕВА, Вильнюсский университет, Литва

\begin{abstract}
Аннотация вительном аспекте. Обобщаются существующие положения относительно происхождения, современного употребления форм и синтаксических функций конвербов, конвербы сопоставляются с точки зрения маркирования глагольных категорий и их отношения к субъекту действия. Отмечается, что основной семантической особенностью конвербов является сопряженность выражаемого ими действия с действием, выраженным опорным глаголом, при которой конвербы локализуют события на временной оси в контексте дейктического значения опорного глагола. С этой точки зрения конвербы представляют собой тип зависимого таксиса, значения которого (одновременность/ предшествование) в русском и литовском языках морфологически реализуются по-разному: в русском - за счет противопоставления, осуществляемого показателями вида, в литовском - за счет противопоставления, осуществляемого показателями времени. На основании анализа русскихи литовских корпусных материалов (НKPЯ и DLKT) устанавливается, что соответствия между данными типами корреляций (деепричастием НСВ - пусдаливисом (полупричастием) или падаливисом настоящего времени, деепричастием CВ - действительным причастием прошедшего времени или падаливисом прошедшего времени) присутствуют в большинстве контекстов при значениях временного отношения, однако в контекстах логического отношения проявляются закономерности другого характера.
\end{abstract}

В работе представлен обзор особенностей русских и литовских конвербов в сопоста-

КЛЮЧЕВЫЕ СЛОВА: конвербы, глагольные формы, глагольные категории, русский язык, литовский язык.

Введение

Термин конверб (англ. converb) в языковую типологию был введен В. П. и И. В. Недялковыми (Nedjalkov \& Nedjalkov, 1987), заимствовавшими его из алтаистики. Под конвербом понимается «глагольное наречие», т. е. «нефинитная форма глагола, основной из функций которой является маркирование адвербиального подчинения» (Haspelmath, 1995, 1999, см. также определения, допускающие более широкую трактовку, в Nedjalkov, 1995, van der Auwera, 1998). Совокупность признаков, выделяемых в определении конверба - нефинитность, принадлежность к парадигме глагола, адвербиальная функция, зависимая позиция - позволяет противопоставить конвербы причастиям, отглагольным существительным и инфинитиву (Haspelmath, 1999, с. 111; Nedjalkov, 1995, с. 97). Несмо- 
тря на то, что применение основанного на данных признаках определения не является беспроблемным (см. обсуждение в Haspelmath, 1995; Ylikoski, 2003; van der Auwera, 1998), термин «конверб» удобен при сопоставлении функционально сходных глагольных форм, традиционно относящихся к разным категориям. В русском языке под определение конверба уверенно попадает деепричастие, а в литовском полупричастие (pusdalyvis), падаливис (padalyvis). В одном ряду с ними также следует рассматривать и литовское действительное причастие прошедшего времени (см. Генюшене, 2014).

В традиционных трудах по грамматике русского языка данные формы трактуются как второстепенное сказуемое (Акимова, Козинцева, 1987; Потебня, 1889 (1958); Шахматов, 1941 (2001)) или зависимый предикат (Биккулова, 2011). Употребление данных форм в традиционной русской и литовской грамматике также относится к типам распространения предложения, объединяемым понятием полупредикативности (Амбразас, 1990; Шведова (ред.), 1970, 19806, с. 181; Ambrazas, 1997; Ulvydas (red.), 1971) и частично термином tarininis pažyminys (букв. 'сказуемое определение', Ambrazas (red.), 2005). Такая трактовка позволяет выносить данные формы за рамки традиционного деления членов предложения на основные (подлежащее, сказуемое) / второстепенные (определение, обстоятельство, дополнение) и рассматривать их отдельно². Основанием этому служит двойная роль таких членов в предложении: они одновременно и синтаксически зависимы, и информативно самостоятельны. Конвербы в этом случае совмещают два значения: обстоятельственное значение и значение сопутствующего (второстепенного) действия. На относительную информационную самостоятельность указывает и характерное для конвербов свойство употребляться не только одиночно, но и, наследуя семантические свойства образующих глаголов, составлять обороты, которые выделяются интонационно и по смыслу соотносятся с придаточными предложениями (ср. читая статью, пил кофе - пока читал статью, пил кофе, и прочитав статью, выпил кофе - когда почитал статью, выпил кофе).

Сопоставлению отдельных черт современных русских деепричастий и соответствующих им форм литовского языка уже частично уделялось внимание. Особенности их функционирования и перевода отмечались в работах Вишняускене (2008), Мустейкис (1972, 2012), Brazauskienè, Miškinienė (2007), Vyšniauskienė, Kravcova (2018), видовые значения литовских конвербов по отношению к русским рассматривались в Вимер (2004, 2009). Тем не менее, дальнейшее сопоставительное исследование свойств русских и литовских конвербов представляется нам полезным как в свете общего понимания лингвистических явлений, так и в свете практического понимания, требуемого в условиях русско-литовского двуязычия.

Целью настоящей работы является обзор и сопоставление основных грамматических и семантических особенностей конвербов в русском и литовском языках. Для достижения этой цели в отдельных главах мы рассмотрим формы и синтаксические функции конвербов с точки зрения происхождения и современного употребления, сопоставим принципы маркирования конвербами глагольных категорий, отметим закономерности функционирования конвербов по отношению к субъекту действия и границы употребления конвербов в речи, выделим наиболее значимые семантические особенности и частотные характеристики конвербов. В качестве основного материала исследования используются данные корпусов HKPЯ и DLKT.

\section{Морфологические показатели, происхождение и синтаксические функции конвербов в русском и литовском языках}

В современном русском языке формы деепричастия образуются посредством присоединения к основе глагола суффиксов -а(-я) (зная, учась), -в/вши/-ши (узнав, нахмурившись). Факторами выбора суффикса при этом является не только вид, но и возвратность, морфонологические особенности глагольной основы, семантико-стилистические функции вариативных форм (Биккулова, 2011; Шведова (ред.), 1980а, с. 670-671).

Аналогичным способом, посредством суффиксов -(i)us,-(i)ant (dirbus, dirbant) образуются и падаливисы. Литовские полупричастия образуются от инфи-

\footnotetext{
${ }^{1}$ В русскоязычной литературе данная форма называется герундием (Амбразас (ред.), 1985; Амбразас, 1990) и несогласуемым причастием (Аркадьев, 2011, 2016). Учитывая аргументы, высказанные в Brazauskiené, Miškiniené (2007), мы в данной статье считаем целесообразным использовать транслитерированный термин.

2 Тем не менее в учебниках (напр., Валгина (ред.), 2002; Вяткина (ред.), 2009) и более старых грамматиках (Виноградов, Истрина (ред.), 1954 (1960), Ulvydas (red.), 1976) конвербы и конвербные обороты рассматриваются как обстоятельства.
} 
нитива глаголов посредством суффикса -dam- и флексий -as, -os, -i, -os, а действительные причастия прошедшего времени образуются от основ глаголов прошедшего времени посредством флексий -е̨s, -usi, -е̨, -usios (Ambrazas (ed.), 1997, c. 333, 334; Ambrazas (red.), 2005, c. 357-358, 361; Ulvydas (red.), 1971, c. 317, 376377). Флексии полупричастий и причастий кумулятивно маркируют относительные временные значения (подробнее об этом - раздел «Семантические особенности конвербов в русском и литовском языках»), род и число (раздел «Субъект действия при конвербах»).

Суффиксы деепричастий происходят от форм именных (кратких) причастий, которые в процессе дифференциации функций причастий в XII-XV веках постепенно утрачивали согласование (Борковский, Кузнецов, 1963 (2006, с. 354-355), Букатевич и др., 1974, с. 222; Зализняк, 2004, с. 184-185; Живов, 2012, с. 181; Пичхадзе, 2016). Формы деепричастий на -а(-я) восходят к форме им. п. муж. р. настоящего времени, формы на -учи - к формам им. п. ед. ч. жен. р. настоящего времени, формы на -в - к формам им. п. ед. ч. муж. и ср. р. прошедшего времени, формы на -вши - им. п. ед. ч. жен. р. прошедшего времени (Борковский, Кузнецов, 1963 (2006, с. 303)).

Исследования первых письменных источников литовского языка (XVI в.) показывают, что соответствующие формы литовских полупричастий и падаливисов, по-видимому, возникли в дописьменный период самостоятельного развития восточно-балтийских языков (Амбразас, 1990; Ambrazas, 1968, 2006). По происхождению суффикс -dama- литовского полупричастия соотносится со страдательным причастием настоящего времени, которое первоначально было залогово нейтральным (см. Амбразас, 1990, с. 100-103), а формы падаливиса представляют собой застывшую форму дательного падежа причастия (Ambrazas, 2006, c. 434; Ulvydas (red.), 1971, c. 385).

В диахронической ретроспективе закрепление за определенными формами роли зависимого предиката в русском и литовском языках происходило сходным путем. Возникновению форм русского деепричастия способствовали изменения в употреблении именных (кратких) причастий, которые, в отличие от местоименных, перестали выполнять роль определения и стали соотноситься не с именной группой, а с главным предложением в целом, что привело к постепенной утрате форм согласования с субъектом действия. Первые примеры несогласованных причастий (сначала по падежу, затем в роде и числе) отмечаются уже в источниках письменности XII-XIII веков в конструкциях при субъекте в дательном падеже с инфинитивом, в «дательном самостоятельном» (dativus absolutus), в винительном падеже (accusativus cum participio) и абсолютных оборотах с имплицитным субъектом, и, как показывают исследования некнижных источников письменности, к XIV в. становятся регулярными (Зализняк, 2004, с. 184-185; Живов, 2012, с. 181; Пичхадзе, 2016).

По данным исследований ранней литовской письменности, основным источником распространения падаливисов также стали конструкции с дательным самостоятельным, из которых застывшая форма дательного падежа причастия в XVI в. стала проникать в аккузативные конструкции, изначально заменяя формы среднего рода и постепенно становясь основной формой в конструкциях типа mačiau tèvq pareinant (Ambrazas, 1968, с. 204; Амбразас, 1990, с. 154-158).

Конструкции с деепричастиями, в которых субъект называемого ими действия не совпадал с номинативным субъектом главной предикации, функционировали и в русской письменности XII-XV веков (Пичхадзе, 2016, с. 506-512), но позже ушли из употребления, уступив место изъяснительным предложениям. Таким образом, в современном русском языке деепричастия выступают исключительно в обстоятельственной (сирконстантной) синтаксической позиции и с этой точки зрения являются несовмещенными (строгими) конвербами (Недялков, 2003):

1 Берлиоз тоскливо оглянулся, не понимая, что его напугало. [М. А. Булгаков, «Мастер и Маргарита», 1929-1940]

Падаливис, в отличии от деепричастия, в современном литовском языке помимо основной обстоятельственной функции (2) продолжает довольно регулярно выполнять комплементативную функцию (хотя и значительное реже, чем обстоятельственную) и выражать сентенциальный актант как, напр., в конструкции типа accusativus cum participio примера (3) (Ulvydas (red.), 1976, с. 384-385, 392; см. также Аркадьев, 2011; Usonienè, Vincent, 2018): 
2 Maks-ui íšvažiav-us,

Макс-DAT.SG уехать-PST.CNV,

Julij-q vèl suèm-e e liūdes-ys.

Юлия-АСС опять охватить-PST.3 грусть-NOM

'Когда Макс уехал, Юлию опять охватила грусть’3 [J. Ivanauskaitė, „Placebas“, 2003] $(\mathrm{DLKT})^{4}$
$<\ldots>$ numan-ème
$j-i$
išvažiav-us.
полагать-PST.2.PL
оH-ACC
уехать-PST.CNV
‘мы полагали, что он уехал’ [Šatrijos Ragana, „Sename Dvare“, 1922]

Литовские полупричастия и действительные причастия прошедшего времени в этом отношении представляют несколько другую картину.

Литовские полупричастия с относительно новым суффиксом -dama- в позиции зависимого предиката заместили более древние формы причастий, которые вместе с тем сохранились в атрибутивной и предикативной позиции (Амбразас, 1990, с. 103; Ambrazas, 2006, с. 362). По сравнению с падаливисом полупричастие является более строгим конвербом и, несмотря на то, что иногда встречается и в изъяснительной функции (5), в большинстве случаев имеет обстоятельственное значение, как в литературном переводе (4) примера (1):

4 Berliozas gailiai apsižvalgè, nesuprasdamas, kas ji išgąsdino. [M. Bulgakovas, „Meistras ir Margarita“, пер. А. Микута, 1985]

5 Lageri-o

$$
\begin{array}{llll}
\text { gydytoj-as } & \text { dar- } \dot{e} & k-q & \text { gale-dam-as }<\ldots> \\
\text { врач-NOM.M.SG } & \text { делать-PST.3 } & \text { что-ACC } & \text { мочь-CON-M.SG }
\end{array}
$$

лагерь-GEN

'Врач лагеря делал, что мог' [V. Mockevičius, „Mirties arterija“, 1994] (DLKT)

Действительные причастия прошедшего времени в свою очередь представляют собой архаичную формy, восходящую к древним индоевропейским отглагольным прилагательным (см. Ambrazas, 2006, с. 352-353), которая сохранила разнообразие функций. Они, наряду с причастиями настоящего и будущего времени, могут употребляться в атрибутивной функции в согласованной с падежом опорного слова форме, также в предикативной функции в рамках парадигмы перифрастических времен, в качестве предикативов и в комплементативной функции. Тем не менее, по наблюдениям исследователей (Амбразас, 1990, с. 107), главной функцией таких причастий является употребление адвербиального типа (аппозитивное употребление причастий). Этим действительные причастия прошедшего времени существенно отличаются от причастий настоящего и будущего времени, что служит доводом в пользу их трактовки в качестве конвербов совмещенного типа (см. также сходную точку зрения в Генюшене, 2014).

Маркирование

глагольных

категорий в

формах русских

и литовских

конвербов
Конвербы в русском и литовском языках сохраняют показатели вида и возвратности производящих глаголов: встречать - встречая; встретить - встретив; встречаться - встречаясь; tikti - tikdamas, tinkant, tikus, tikęs; sutikti - sutikdamas, sutinkant, sutikęs, sutikus; susitikti - susitikdamas, susitinkant, susitikęs, susitikus.

В русском языке данные характеристики влияют на формообразовательный тип деепричастия. Хотя первоначально деепричастия с разными суффиксами образовывались от глаголов обоих видов, напр.: встречая, встречав; встретя, встретив (см. Якобсон, 1972, с. 107-108), примерно с середины XIX века отмечается тенденция связывать суффикс с видом: суффикс -а стал тяготеть к глаголам несовершенного вида (НСB), суффиксы -в/-вши - к глаголам совершенного вида (СВ), в связи с чем деепричастия прошедшего

\footnotetext{
3 Перевод данного и следующих примеров предложен авторами статьи. В остальных случаях указывается автор литературного перевода (см. пример 15).

${ }^{4}$ Здесь и далее в квадратных скобках отмечается первичный источник, в круглых скобках - вторичный источник.
} 
времени от глаголов НСВ и настоящего времени от глаголов СВ начали с разной скоростью выходить из употребления (Добрушина, 2009, с. 16; Ковтунова, 1964, с. 376; Абдулхакова, 2007). В результате формообразование деепричастий в современном русском языке представляет собой сравнительно сложную картину морфонологических и стилистических типов и вариантов (см. Добрушина, 2009, с. 30-31; Шведова (ред.), 1980а, с. 670-671): а) значительное число глаголов НСВ (напр., вязать, гнуть, гаснуть) вообще не образует деепричастий, или образует малоупотребительные деепричастия (напр., ждя, рвя); б) глаголы с вариативной основой настоящего времени образуют стилистически равноправные формы с тем же суффиксом, ср, брызжа и брызгая, махая и маша, тыча и тыкая; в) у некоторых деепричастий сохраняется вариативность равнозначных типов, напр., от возвратных глаголов на -ить возвратясь/возвратившись, нахмурясь/нахмурившись; г) некоторые глаголы несов. вида сохраняют дифференцирование форм настоящего и прошедшего времени (особенно при отрицании), напр., читая - читав, будучи - быв; д) значительная часть глаголов при нейтральном варианте на -а имеют стилистические варианты на -ши, -учи, напр., найдя - нашедши, идя - идучи; е) некоторые устаревшие варианты сохраняют регулярность во фразеологизмах, напр.: положа руку на сердце, сложа руки. Литовские конвербы в этом отношении единообразны: они не имеют вариативных форм ${ }^{5}$ и морфонологически обусловленных ограничений формообразования.

С точки зрения вида и времени в современных грамматиках и учебниках принято различать только два типа деепричастий: деепричастия НСВ, формы которых образуются от основ настоящего времени посредством суффикса -а(-я), и деепричастия СВ, формы которых образуются от основ прошедшего времени посредством суффиксов -в/-вши/-ши или (реже) суф. -а (Валгина, 2002; Шведова (ред.), 1970, с. 422423; Шведова (ред.), 1980а, с. 670). Деепричастия данных типов коррелируют между собой так же, как и другие формы соответствующих видовых пар глаголов (см. раздел 2).

Корреляции форм конвербов в литовском языке в свою очередь основаны на противопоставлении, осуществляемом показателями настоящего и прошедшего времени: полупричастие - действительное причастие прошедшего времени, падаливис настоящего времени - падаливис прошедшего времени

По поводу категории вида в литовском языке следует отметить, что она грамматикализована в меньшей степени, чем в русском, о чем требуется сказать несколько слов. Литовский язык обладает богатым набором глагольных приставок и суффиксов, которые участвуют в образовании глагольных пар, сходных с русскими, напр., dar-yti 'делать' - pa-dar-yti 'сделать', skait-yti 'читать' - per-skait-yti 'прочитать', šauk-ti 'кричать' - šūk-tel-èti 'крикнуть', поэтому традиционно в литовской грамматике выделяются два вида глаголов: eigos veikslas - процессуальный вид, соотносимый с русским НCB, и įvykio veikslas - событийный вид, соотносимый с русским СВ. При этом парадигма грамматических времен глагола в литовском языке позволяет образовывать любые формы как от глаголов процессуального, так и событийного вида, а видовое противопоставление глаголов в разных временных планах проявляется по-разному: в плане прошедшего времени в большинстве контекстов - как противопоставление «длительность - событийность», ср., skaitè laiškus “читал письма' - perskaitè laiškus 'прочитал письма', а в плане настоящего - чаще как «длительность - хабитуальность/итеративность», ср., skaito laiškus 'читает письма' - perskaito laiškus 'прочитывает письма' (Аркадьев, 2012, с. 53-54; Paulauskienè, 1979, с. 69, 78). На этом основании в традиционных грамматиках литовского языка также выделяется группа т. н. двувидовых глаголов (Ambrazas (red.), 2005, c. 289; Ulvydas (red.), 1971, c. 40-44), напр. grižti: grižo 'вернулся' - grižta 'возвращается'.

В связи с этим традиционно считается, что литовские глагольные пары составляют лексико-семантическую категорию (Амбразас (ред.), 1985, с. 199-202; Галнайтите, 1963, Ambrazas (red.), 2005; Paulauskienè, 1979, с. 55-84), а в более новых исследованиях (Вимер, 2001, 2004; Аркадьев, 2008, 2009, 2012), пере-

\footnotetext{
5 Данное утверждение не относится к диалектным вариантам произношения и употребления конвербов (cм. Ulvydas (red.), 1971, с. 377-378).

6 Другие формы падаливиса в этом случае нерелевантны: падаливис прошедшего хабитуального (напр., dirbdavus) используется чрезвычайно редко (в аннотированной части DLKT таких менее 0,00001\% от всего объема корпуса), а падаливис будущего времени (dirbsiant) используется только в конструкциях accusativus cum participio (см. предыдущий раздел, также cм. Ulvydas, red. 1976, с. 384-385, 392).
} 
сматривающих традиционные взгляды на аспектуальную систему литовского языка, вместо описания общего видового противопоставления предлагается описание противопоставлений акциональной семантики глагольных лексем, типов их словообразования и контекстов.

Слабая грамматикализованность категории вида проявляется также в том, что в литовском языке нет видовых ограничений на образование конвербов: формально они могут образовываться как от глаголов процессуального, напр., daryti: daręs, darydamas, darius, darant, так и от событийного вида, напр., рadaryti: padaręs, padarydamas, padarius, padarant (см. Ulvydas (red.), 1971, с. 384).

Тем не менее для значений литовских конвербов существенны аспектуальные свойства образующих глаголов и их «поведение» в определенном временном плане. Так, в адвербиальной функции в значении предшествования употребляются только действительные причастия и падаливисы событийного (padaręs, padarius 'сделав') и двувидового типа (grižęs, grižus 'вернувшись', ср. с grižo 'вернулся'), тогда как в значении одновременности могут употребляться не только конвербы глаголов процессуального типа (darydamas, darant 'сделав'), но и глаголы, традиционно относимые к двувидовому (griždamas, grižtant 'возвращаясь', ср. с grižta 'возвращается') и событийному типам (padarydamas, padarant). Количество таких примеров в художественных текстах аннотированного корпуса DLKT составляет примерно 18-26\% от всего количества употреблений полупричастий и падаливисов настоящего времени в данном субкорпусе.

Пассивный залог у конвербов в русских традиционных грамматиках не рассматривается. Тем не менее, возможен подход (Биккулова, 2011, см. также Недялков, 2003, с. 170; Пешковский, 1956 (2001, с. 122)), при котором деепричастными формами пассивного залога могут считаться: а) конструкции с деепричастием будучи и страдательным причастием (аналитическая форма), напр., будучи загипнотизированным; б) возвратная форма деепричастий (синтетическая форма), напр., строясь, создаваясь, употребляемая в основном в контекстах описания создания чего-либо (см. Биккулова, 2011).

Примеры, в которых полупричастие būdamas выполняет роль связки в пассивной конструкции, можно найти в текстах, где такое употребление бывает оправдано с точки зрения однородности членов предложения:

$6<\ldots>$ sirgdamas nepagydoma liga ir būdamas pasmerktas, $<\ldots>$ Augnelijus nutaré susinaikinti $<\ldots>$ 'будучи неизлечимо больным (букв. «болея»), обреченным, Аугнелиюс решил уничтожить себя' [S. Spurga, „Pasaulio vidurys”, 2000] (DLKT)

7 <..> žmogus mylèdamas ir būdamas mylimas gerai jaučiasi <...> 'человек, любя и будучи любимым, хорошо себя чувствует' [G. Vasiliauskienè, „Ilgo gyvenimo receptas optimizmas", 2009, https://www.lrytas.lt/]

Аналогично, форма страдательного залога в конструкциях с падаливисами būnant, buvus востребована в текстах судебного дискурса:

$8<\ldots>$ negalint būti renkamais ị atitinkamų savivaldybių tarybas ir būnant ịrašytais j̣ kurị nors ne politinès partijos sq̨rašą kaip kandidatai ị savivaldybių tarybų narius <...> 'не имея возможности избираться в собрания соответствующего муниципального округа и будучи включенными в партийные списки в качестве кандидатов в члены собрания муниципального округа' [Vilniaus apygardos administracinis teismas, „Nutartis dèl rinkimų rezultatų pripažinimo negaliojančiais “, 2007]

$9<\ldots>$ itarti buvus padaryta nusikalstama veikq <...> 'подозревать, что были осуществлены преступные действия’ [Klaipėdos apygardos teismas, „Nutartis dèl žalos atlyginimo priteisimo“, 2017]

Субъект действия при конвербах
Особенностью русских деепричастий является совпадение субъекта действия деепричастия и глагольной формы:

10 Еще более побледнев, он вытаращил глаза <...> [M. А. Булгаков, «Мастер и Маргарита», 1929-1940] 
С этой точки зрения в литовском языке им эквивалентны полупричастия и причастия прошедшего времени, которые в отличие от деепричастий согласуются с субъектом действия флективно в роде и числе, см. литературный перевод предыдущего примера:

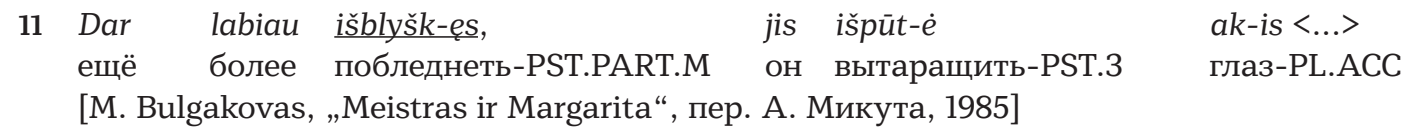

Падаливис в этом смысле выполняет противоположную функцию и указывает на разнореферентный субъект’:
12 Saul-ei
tek-ant,
pasiek-èm
kryžkel-ę. солнце-DAT восходить-PRS.CNV добраться до-PST.1.PL перекрёсток-ACC
'На восходе мы вышли на перекрёсток' (LKG)

Примечательно, что в современных русских грамматиках и справочниках относительно принципа однореферентности приводятся некоторые дополнения. В частности, указывается что деепричастные обороты ненормативны: а) в пассивных конструкциях, так как в них подлежащее означает одновременно и субъект состояния и объект действия, напр., *Получив большое количество пробоин, танк был подожжен; 2) в безличных предложениях, напр., *'Выполняя это поручение, ему не хотелось огласки, однако при этом употребление деепричастия допускается, если в состав предложения входит другая глагольная форма (инфинитив, причастие или деепричастие): Увидев, что он еще жив и борется, мне захотелось оказать ему немедленную помощь. Ничем нельзя было удержать напора волн, нахлынувших на берег, сметая все на своем пути. (Розенталь и др. 1998, с. 320-321; Шведова (ред.), 1980б, с. 182). Одновременно с этим в речи постоянно фиксируются нарушения этого правила, в связи с чем исследователи в некоторых случаях подвергают сомнению его строгость, отмечая, что некоторые формально некорректные предложения поддаются осмыслению (Гловинская, 1996; Ицкович, 1982; Йокояма, 1983; Онипенко, Биккулова, 2016; Шмелева, 1984). Как показывает анализ, представленный в Онипенко, Биккулова (2016), это происходит в случаях, когда субъект деепричастия совпадает с субъектом модуса в 1-ом лице, но не совпадает с субъектом диктума:

13 Перечитывая одну брошюру о лимонах, меня вдруг осенила мысль, что лимонная кислота прекрасно справится с дезинфекцией желудка. [А. Я. Яшин, «Питание каратиста», журнал «Боевое искусство планеты», 2003]

В литовском языке полупричастия и причастия не допускают такой неоднозначности, так как всегда согласуются с подлежащим по роду и числу посредством флексии и даже в спонтанной речи, как правило, отвечают принципу однореферентности ${ }^{8}$.

Поэтому падаливис не только выполняет роль обстоятельства, когда субъект действия падаливиса и основного глагола не совпадает, но и во всех пограничных случаях: а) в безличных предложениях (14); б) при совпадении имплицитного субъекта действия падаливиса и основного глагола и одновременном несовпадении формального (грамматического) субъекта (15); в) при частичном (не)совпадении субъекта, когда второстепенное действие выполняется группой, а основное - только одним из ее членов (16):

14 Ilgai долго mylëj-us,

sunku pames-ti букв. 'долго любив, тяжело потерять' [поговорка] потерять-INF

15 Dabar, nakti сейчас ночь:АСС bežygiuoj-ant идти(в-походе)-PRS.CNV

\footnotetext{
7 О несоответствиях принципу разнореферентности в говорах см. Ulvydas (red.), 1971, с. 390.

${ }^{8}$ Следует признать, что в речи носителей иногда отмечаются ошибки согласования причастий прошедшего времени по роду во множественном числе.
} 

jam vokiškas
sunkvežim-is
pervaž-iavo
koj-q, $<\ldots>$
он:DAT немецкий
грузовик-NOM
переехать-PST.3
нога-АCC

'В нашем последнем ночном походе немецкий грузовик переехал ему ногу' [B. Sruoga, „Dievų miškas“, 1957, пер. Г. Канович, Ф. Шуравин, 1981] (LKG)

\begin{tabular}{llll} 
Atsisveikin-ant & ponas & \multicolumn{1}{c}{ Kalvaitis } & man \\
Прощаться-CNV.PRS & господин-NOM & \multicolumn{1}{c}{ Калвайтис-NOM } & я. DAT \\
padovanoj-o & dail-iq & pypk-ę. & \\
подарить-PAST.3 & красивая-ACC & трубка-АCC
\end{tabular}

'Когда мы прощались, господин Калвайтис подарил мне красивую трубку' [R. Lankauskas, „Likimo zona“, 1998] (DLKT)

\section{Переход конвербов в другие классы частей речи (адвербиализация, грамматикализация)}

В некоторых случаях конвербы претерпевают изменения актантной и семантической структуры, утрачивают связь с парадигмой образующего глагола и информативную самостоятельность. Такие изменения свидетельствуют об адвербиализации деепричастий и падаливисов (Биккулова, 2011; Виноградов, Истрина, Бархударов (ред.), 1954 (1960, с. 524); Ковальская, 2016; Birzer, 2010; Ulvydas (red.), 1971, с. 396). В связи с ней в русском языке к производным наречиям часто относятся лежа, сидя, шутя,

глядя, в литовском -- падаливисы bematant 'видя', bežiürint 'смотря', beregint 'глядя', beverkiant 'плача', netrukus 'вскоре'. Такие слова также утрачивают актуальную связь с субъектом, в связи с чем требование односубъектности/разносубъектности теряет силу:

17 Правда разместить больного лежа внутри салона вряд ли удастся. [http://bmwer.ru] (РКГ)

18 Nepanašus ị jokị ligtol matytą drambli, jis vis dèlto neabejotinai buvo loxodonta africana. Bematant pamilau. 'Не похожий ни на какого до этого виденного слона, он все же определенно был loxodonta africana. Сразу (букв. «видя») влюбилась' [E. Juodvalkè, „Cukraus kalnas", 2000] (DLKT)

Примечательно, что иногда конвербы адвербиализируются вместе с зависимыми словами в составе устойчивых выражений: сложа руки, спустя рукава, neilgai trukus 'вскоре', kaip reikiant 'как следует'.

В некоторых случаях деепричастия и падаливисы утрачивают обстоятельственное значение, но сохраняют глагольное управление и начинают выполнять роль предлогов (Биккулова, 2011; Ulvydas (red.), 1971, с. 397). Примерами такой смены функции являются спустя, смотря (по), благодаря, начиная (c), nepaisant 'несмотря на', neskaitant 'не считая', išskyrus 'кроме', išskiriant 'выделяя'.

Следует отметить, что такие предлоги, а также некоторые деепричастия и падаливисы используются в составе союзов и связующих фраз, напр., nepaisant to, kad (jog) - несмотря на то, что; sprendžiant iš to, kad (jog) - судя по тому, что; grižtant prie - возвращаясь к:

19 Sokrato veikla yra politine nepaisant to, kad ji netelpa i konvencinès „politikos“ rémus. 'Деятельность Сократа является политической, несмотря на то, что она не входит в рамки конвенциональной «политики» [M. Adomènas, „Plato Christianus“, в сборнике „Tikèjimo prieigos“, (sud.) N. Putinaitè, 2003] (DLKT)

$20<\ldots>$ sprendžiant iš to, jog „Lietuvos telekomas“ kels kainas, „Bitès GSM“ išlaidos taip pat padidès. 'судя по тому, что <название> будет повышать цены, расходы <название> также повысятся' [газета „Lietuvos rytas“, 2011] (DLKT)

21 Taigi, grižtant prie mūsu problemos, tam tikrame tekste arba tokio ir tokio autoriaus kūryboje egzistuoja idejjos, susijusios tam tikrais ryšiais, <...> 'Таким образом, возвращаясь $\mathrm{k}$ нашей проблеме, в определенном тексте или творчестве такого-то и такого-то автора существуют идеи, связанные определенными связями' [L. Donskis, „Ideologija ir utopija nūdienos civilizacijos istorijoje“, 1996] (DLKT) 
Литовские полупричастия и причастия обладают маркирующими согласование флексиями и сохраняют тесную связь с субъектом, в связи с чем не подвергаются процессам адвербиализации и грамматикализации.

Семантические особенности конвербов в русском и литовском языках

Основной семантической особенностью конвербов как формы глагола является сопряженность выражаемого ими действия (или состояния) с действием (состоянием), выраженным основным (опорным) глаголом. Данная сопряженность предполагает определенное временное (или иногда логическое) отношение, поэтому временные значения действий, выражаемые конвербами в русском и литовском языках, являются относительными: конвербы локализуют события на временной оси только в контексте дейктического значения опорного глагола. С этой точки зрения они представляют тип зависимого таксиса и могут считаться специализированной формой его выражения (Акимова, Козинцева, 1987; Храковский, 2009; Якобсон, 1971).

В русском языке основным средством реализации таксисных значений (одновременности, предшествования или разновременности, следования) является видовое противопоставление глаголов (Маслов 2004:311). Соответственно, русские деепричастия НСВ выражают действие, пересекающееся во времени с действием основного глагола (общее значение одновременности, примеры 22, 23), а деепричастия СВ выражают: а) действие, предшествующее действию, выраженному опорным глаголом (24), б) действие, предшествующее и вызвавшее состояние, сопутствующее действию, выраженному опорным глаголом (25):

22 -Товарищ, Бездомный, помилуйте, - ответило лицо, краснея, пятясь и уже раскаиваясь. [М. А. Булгаков, «Мастер и Маргарита», 1929-1940]

$23<\ldots>$ необходимо, сохраняя удлинение образиа, замерять изменения в величине растягивающей силы. [В. И. Феодосьев, «Сопротивление материалов», 1975]

24 Испуганно ойкнув, женщина со всех ног бросилась к хате <...> [В. Быков, «Болото» (2001)] (НКРЯ)

25 Я стоял, склонившись над бортовыми поручнями. [Ф. Искандер, «Начало», 1969] (НКРЯ)

В литовском языке в большинстве случаев данные значения реализуются за счет противопоставления коррелирующих форм конвербов (Ulvydas (red.), 1971, с. 356): значение одновременности имеют полупричастия (26) и падаливисы настоящего времени (27), а значение предшествования имеют действительные причастия (примеры 28, 29) и падаливисы прошедшего времени (30).

26 - To ir betrūko, kad imtumèvos savo tarpe žodžiuotis, - tarè Juozas, sunkiai atsidusdamas, ir susimąsté, klajodamas akimis po linkinę ir sodiečiu butus. 'Не хватало еще начать между собой ругаться, - сказал Юозас, тяжело вздохнув, и задумался, скользя взглядом по местности и жилищам сельчан' [Lazdynų Pelėda, „Ir pražuvo kaip sapnas“, конец XIX в.]

$27<$ <..> reikia išmatuoti tempimo jègos kitima, išsaugant pastovų bandinio ištịsima. ${ }^{9}$ [V. Feodosjevas, „Medžiagų atsparumas“, 1977, ред. перевода M. Remišauskas]

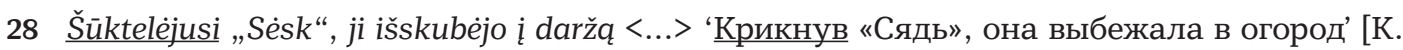
Barėnas, „Dvidešimt viena Veronika“, 1997] (DLKT)

29 Aleksandras sèdèjo palinkęs prie stalo ir rūkè. 'Александр сидел согнувшись за столом и курил' [V. Katilius, „Dykumos karalius“, 1996] (DLKT)

$30<\ldots>$ atvykus Petrui, visi gydytojai buvo akylai stebimi <...> 'когда Пятрас приехал, за всеми врачами велось наблюдение' [G. Aleksa, „Adomo broliai ir moterys“, 2001] (DLKT)

\footnotetext{
${ }^{9}$ Перевод примера 23.
} 
В зависимости от контекста (определенного соотношения видо-временых форм конверба и сказуемого, акционального типа и лексического значения глаголов, позиции конверба относительно сказуемого, наличия/отсутствия отрицания при конвербе или сказуемом, наречия и других обстоятельств времени), наряду с общими значениями одновременности/предшествования, конвербы могут иметь более конкретные значения.

С точки зрения того, каким образом соотносятся временные границы сопряженных ситуаций (подробнее см. Бондарко, 1987а; Муравьев, 2017; Полянский, 1987), данные значения могут представлять разные типы: одна ситуация может включать другую (примеры 31, 32), ситуации (действия) могут быть строго одновременными $(33,34,35)$, частично пересекаться $(36,37)$ или иметь неопределенные границы $(38,39)$ :

31 Он пробормотал что-то и пошёл к себе в комнату, успел, проходя по коридору, дважды nосмотреть на часы. [В. Гроссман, ЖЖизнь и судьба», ч. 3, 1960] (НКРЯ)

32 Eidamas koridoriumi, dirstelèjo ji veidrodị, pačiupinèjo ranka skruosta, stabtelèjo, kažką pagalvojo ir, staiga apsisukęs, pravèrè miegamojo duris. 'Идя по коридору, взглянул в зеркало, потрогал рукой щеку, остановился и, быстро развернувшись, открыл дверь спальни’ [B. Radzevičius, „Vakaro saulë“, 1996] (DLKT)

33 Я молчал, не зная, что сказать. [В. Белоусова. «Второй выстрел», 2000] (НКРЯ)

$34<\ldots>$ valandèlę tylëjau, nežinodamas, kaip pradèti kalba <...> 'мгновение (я) молчал, не зная, как начать разговор’ [V. Dautaras, „Jazminas tèvo sode“, 1995] (DLKT)

35 Gera spręsti kitų problemas gulint lovoje. 'Хорошо решать чужие проблемы лежа в кровати' [H. Kunčius, „Būtasis dažninis kartas“, 1998] (DLKT)

36 Испуганные гости, стараясь не замечать неприличия, спешно заговорили кто о чём. [И. Грекова. «На испытаниях», 1967] (НКРЯ)

37 Prisiversdamas pradejo pirmaji sakini <...> 'Сделав над собой усилие, начал первое предложение' [R. Granauskas, „Kenotafas“, 2005] (DLKT)

38 Кто-то спал в этом доме, кто-то стерег чей-то покой, дремля на пороге за входною дверью. [Ф. К. Сологуб, «Королева Ортруда», 1909] (НКРЯ)

39 Kiek pailsinu sqnarius, guledamas ant kilimo <...> 'Немного расслабляю суставы, лежа на ковре' [V. Zaikauskas, „Pèdsakai baigiasi rojuje“, 2000] (DLKT)

Сопряженность действий, выражаемых конвербом и опорным глаголом, также может проявляться в разной степени и иметь разные семантические оттенки. В контекстах характеризации действия (состояния), при котором сопряженность имеет значение образа действия (примеры 25, 29, 39), часто проявляется семантическая близость глаголов, и иногда частичная контекстуальная взаимозаменяемость (стоял у борта = наклонился над бортом, отдыхал = лежал). В других случаях на передний план выходит не семантическая близость действий, а определенный тип отношения между действиями. Отношение может иметь необусловленный характер (примеры 24, 28) либо характеризоваться определенными типами обусловленности: временной, причинно-следственной и др.

Отношение временной обусловленности проявляется в семантике глаголов, а также может подчеркиваться дополнительными временными маркерами как-то - kartą, только - tik, dar - еще:

40 Как-то, возврашаясь со службы, Евгения Николаевна встретила Лимонова. [В. Гроссман, «Жизнь и судьба», ч. 1, 1960] (НКРЯ)

41 И только подойдя совсем близко, увидел её. [И. Муравьева, «Мещанин во дворянстве», 1994] (НКРЯ) 
42 Rado ji Fortunatas, dar būdamas paauglys, pamišky, savo karves atginęs. 'Фортунат нашел его <ружье> будучи еще подростком, на опушке, выгоняя коров’ [H. A. Čigriejus, „Sugrịžusi upe““, 1995] (DLKT)

43 Ir tik grižęs prie mokytojo staliuko, sulaukiu jos dèkingo žvilgsnio. 'Как только я вернулся $\mathrm{K}$ столу учителя, сразу же встретил ее благодарный взгляд’ [P. Venclovas, „Aistrų fiesta“, 1997] (DLKT)

44 Karta grižtant iš darbo ir lietuviškai kalbant prie ju prièjo bernaitis, <...> 'Однажды, когда они возврашались с работы и разговаривали между собой по-литовски, к ним подошел паренек' [R. Kalytis, „Juodanugarių laikai“, 2002] (DLKT)

Помимо временной обусловленности, действия конверба и опорного глагола также могут быть связаны причинными (примеры 33, 34), условными $(45,46,47)$, уступительными $(48,49)$, целевыми $(50,51)$ отношениями:

45 Начав делать реформы, надлежит отказаться от самодержавия, которое есть злая ложь. [О. Д. Форш, «Одеты камнем», 1924-1925] (НКРЯ, РКГ)

46 Выбрав в списке главного окна управляющего интерфейса требуемую отладочную точку, пользователь может изменить её параметры. [А. Ю. Савинков. «Синхронизация и верификация в имитационном моделировании», 2004] (НКРЯ)

$47<$ <..> nukritus asteroidui nemokéčiau skolu <...> 'если бы упал астероид, я бы не платила долгов’ [U. Radzevičiūtè, „Strekaza“, 2003] (DLKT)

48 Говорил он так, что, даже не видя его лица, вы по одному звуку его голоса чувствовали, что он улыбается. [И. С. Тургенев. «Ася», 1858]. (НКРЯ)

49 Istorija apie moteri, kuri išliko gyva laineriui nukritus Sibiro taigoje <...> 'История о женщине, которая осталась жива после падения лайнера в сибирской тайге' [J. Ivanauskaitè, „Placebas“, 2003] (DLKT)

50 Киваю, стараясь быть сдержанным, <...> [В. Сорокин, «День опричника», 2006]

51 Linkteliu, stengdamasis laikytis santūriai, <...> ${ }^{10}$ [V. Sorokin, „Opričniko diena“, пер. Б. Янушявичюс, 2008]

Примечательно, что литовские конвербы в оборотах с выступающими в адвербиальной функции предлогами prieš ('перед тем как') и iki ('до того как'), а также с наречием netrukus ('вскоре') имеют значение следования:

52 Apgailestauju, kad prieš susipažindamas delnu perbraukiau kelnių klešnę. 'Сожалею, что перед знакомством я ладонью провел по штанине' [H. Kunčinas, „Būtasis dažninis kartas“, 1998] (DLKT)

53 Prieš tau ateinant, mano sargybinis viska patikrino. 'До того как ты пришел, мой охранник все проверил’ [A. Pelenis, „Keturiolika Restitucijos dienu““, 1997] (DLKT)

54 Vilniaus universitete ekonomikq baigusi moteris iki gimstant vaikams dirbo viename projektavimo institute, <...> 'Женщина, получившая экономическое образование в Вильнюсском университете, до рождения детей работала в одном институте проектирования' [A. Arlauskaitè, „T. Šernas: vakar buvo rytoj“, 2006] (DLKT)

\footnotetext{
10 Перевод примера 50.
} 
Возможность значения следования у деепричастий также отмечается в грамматиках русского языка. Вот несколько примеров:

55 После бурного припадка рвоты мать уложила его в постель, накрыв бледный лоб мокрым полотенцем. [М. Горький, «Мать», 1906] (Акимова, Козинцева, 1987, с. 263)

56 <..> хохол выбирал книги из чемодана, ставя их на полку у печки [М. Горький, «Мои университеты», 1923] (Валгина (ред.), 2002)

57 Он быстрыми костлявыми пальиами расстегнул сюртук, открыв рубаху навыпуск, медные пуговицы жилета и цепочку часов <...>. [Л. Толстой, «Анна Каренина», 1977] (РГ)

Однако выделение семантики следования у деепричастий в данных примерах представляется спорным (см. сходную точку зрения в Биккулова 2016). Примеры $(55,56)$ могут рассматриваться как тип употребления деепричастий, при котором глагол и деепричастие выражают сопряженные действия в рамках единого процесса. В ситуации (55), как отмечают Акимова, Козинцева (1987, с. 263), действие, отмеченное деепричастием, спаяно с действием, выраженным глаголом, и является его «завершением».

Пример (56) в этом смысле аналогичен примеру (55), с той лишь разницей, что оба действия в данной ситуации неоднократны, чем можно объяснить использование деепричастия НСВ.

Пример (57), в свою очередь, передает не временное следование, а значение логического следствия и представляет собой тип употребления конвербов, который следует отнести к отдельной группе. В рамках этой группы рассматриваются конвербы, выражающие не второе действие, а интерпретацию основного действия, или указывающие на действие, которому дается оценка (см. понятия псевдовременности в Бондарко, 19876, и Полянский, 1987, интепретативно-оценочного отношения в Акимова, Козинцева, 1987, коинциденции в Вимер, 2004)11. Можно выделить такие семантические типы данного употребления конвербов: а) способ осуществления действия (примеры 58, 59); б) случайное физическое следствие (60, 61) или целенаправленный результат $(62,63)$; в) логическое следствие или оценка действия $(64,65)^{12}$ :

$58<\ldots>$ покончил в пути жизнь самоубийством, приняв яд. [Владимир Макаров. Неслыханная удача фюрера // «Родина», 2008] (НКРЯ)

$59<\ldots>$ Akutagava nusižudè, prarydamas mirtina dozę veronalio. 'Акутагава совершил самоубийство, приняв смертельную дозу веронала' [Р. Venslovas, „Teateinie meilès karalyste்“, 2002] (НКРЯ)

60 При этом он [лев] задел лапой мое правое плечо, разодрав комбинезон, а заодно и вырвав кусок кожи вместе с мускульной тканью. [В. Шефнер, «Лачуга должника», 1981(2008)] (НКРЯ)

$61<\ldots>$ pirmininko E. Galvanausko bute sprogo bomba, apysunkiai sužeisdama ministrq. 'В квартире Э. Галванаускаса взорвалась бомба, серьезно ранив министра' [L. Truska, „Antanas Smetona ir jo laikai“, 1995] (DLKT)

62 И она встала перед Глебовым, загородив его, будто Ганчук мог в Глебова чем-то кинуть. [Ю. Трифонов, «Дом на набережной», 1976] (НКРЯ)

$63<\ldots>$ dabar jau laisva dešine ranka apkabinau ją per liemeni, delnu pajusdamas, ko ir noréjau - standžiq krūtị <...> ‘(я) теперь уже свободной правой рукой обнял ее за талию,

\footnotetext{
11 Если следовать узкому определению категории таксиса, такие примеры следует выносить за ее рамки (см. понятие коинциденции в Вимер, 2004). Однако, возможен и другой подход с более широкой трактовкой таксиса (см. понятие псевдоодновременности в Полянский 1987, с. 250-253; также Бондарко, 1987, с. 236), основанием к которой служит довод о том, что в ментальной плоскости любое явление может мыслиться как несколько сопряженных (и, следовательно, одновременных) признаков, выражаемых двумя предикациями (Бондарко, 1987, с. 236).

12 Как правило, в предложениях логического следствия употребляются постпозитивные конвербы, образованные от глаголов интерпретации, напр., ошибиться, оплошать (Rheuther, 2011).
} 
ладонью ощутив то, чего и хотел - упругую грудь’ [A. Eidintas, „Erelio sparnų dvelksmas“, 2008] (DLKT)

64 Ошибся, что ли, приняв осень за весну? [И. Грекова, «Под фонарем», 1963] (НКРЯ)

65 Padariau klaida tave i namus dar maža parsinešdamas. 'Я сделал ошибку, принеся тебя еще маленькую домой’ [L. Gutauskas, „Daiktai”, 2008] (DLKT)

С морфосинтаксической точки зрения в данных предложениях видовые формы деепричастия не примыкают с определенным значением одновременности/предшествования к опорному глаголу, а «согласуются» с ним по виду. В литовском языке в данных случаях довольно часто (см. анализ в Вимер, 2004) выступают полупричастия, образованные от приставочных глаголов. Чаще всего замена таких полупричастий бесприставочными полупричастиями или приставочными причастиями недопустима, так как в первом случае возникло бы значение образа действия (ср. пример 36), в во втором - последовательности действия (ср. пример 25).

Функционально-стилевые особенности употребления русских и литовских конвербов
Значения и функциональные особенности конвербов в разной степени востребованы в зависимости от конкретных целей текста. Поэтому частотное распределение конвербов по функционально-стилистическим пластам языка неравномерно (таблица 1).

Таблиц 1 Частотность конвербов в подкорпусах HKPЯ и DLKT ${ }^{15}$

\begin{tabular}{|c|c|c|c|c|c|c|c|c|}
\hline & \multicolumn{4}{|c|}{ конвербы одновременности } & \multicolumn{4}{|c|}{$\begin{array}{c}\text { конвербы предшествования } \\
\text { (разновременности) }\end{array}$} \\
\hline & 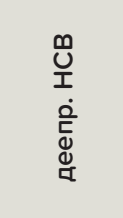 & 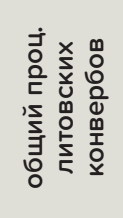 & 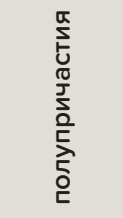 & 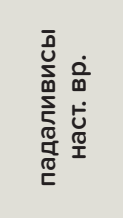 & 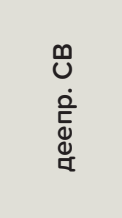 & 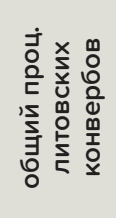 & 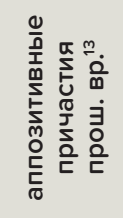 & 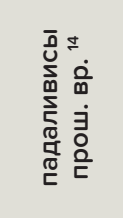 \\
\hline художественная л. & $0,551 \%$ & $0,282 \%$ & $0,228 \%$ & $0,054 \%$ & $0,283 \%$ & $0,515 \%$ & $0,464 \%$ & $0,051 \%$ \\
\hline публицистика & $0,300 \%$ & $0,460 \%$ & $0,221 \%$ & $0,239 \%$ & $0,170 \%$ & $0,361 \%$ & $0,218 \%$ & $0,143 \%$ \\
\hline учебно-научная л. & $0,243 \%$ & $0,640 \%$ & $0,318 \%$ & $0,322 \%$ & $0,073 \%$ & $0,331 \%$ & $0,195 \%$ & $0,136 \%$ \\
\hline официально-деловая л. & $0,209 \%$ & $0,317 \%$ & $0,120 \%$ & $0,197 \%$ & $0,053 \%$ & $0,166 \%$ & $0,048 \%$ & $0,118 \%$ \\
\hline устная речь & $0,112 \%$ & 0,179\% & $0,061 \%$ & $0,118 \%$ & $0,026 \%$ & $0,181 \%$ & $0,119 \%$ & $0,062 \%$ \\
\hline
\end{tabular}

13 Частотность аппозитивных причастий была вычислена с учетом коэффициента $(0,4)$, полученном в результате анализа механической выборки.

14 При расчете частотности падаливисов прош. вр. в выборке были выявлены и исключены омонимичные формы действительных причастий жен. р. с усеченным окончанием (напр., еsu buvus, esu mačius).

15 Расчет был произведен по данным корпуса НКРЯ со снятой омонимией и данным аннотированной части корпуса DLKT http://corpus.vdu.lt/. Мы не располагаем данными аналогично выполненных исследований, однако в общей сумме частотность полупричастий и падаливисов сопоставима с данными, полученными в Rimkutè, 2006. 
По полученным данным, русские деепричастия наиболее частотны в художественных текстах (0,8\% от общего объема субкорпуса художественной литературы). В этом типе текстов конвербы служат средством компрессии и связности, что позволяет разнообразить динамичность письменного художественного повествования (ср. примеры 22 и 26, 24 и 28).

Для литовских художественных текстов также характерна высокая частотность конвербов, в особенности аппозитивных причастий, которые составляют 0,5\% субкорпуса художественной литературы. Тем не менее, по данным DLKT, литовские конвербы наиболее частотны в текстах учебно-научной литературы (1\% от общего объема субкорпуса), и именно этот функциональный стиль является доминирующей речевой средой употребления полупричастий и падаливисов настоящего времени.

Согласно данным устного корпуса НКРЯ, деепричастия составляют лишь 0,1\% от общего объема субкорпуса устной речи, что подтверждает отмечаемую лингвистами тенденцию редкого использования деепричастий в современной разговорной речи (Земская (ред.), 1973, с. 168; Кибрик, Подлесская, 2009, с. 233; Куприна, Матвеева, 2013, с. 216). Это можно объяснить тем, что в устной речи связность текста в гораздо меньшей степени обеспечивается синтаксическими средствами, а из глагольных предпочитаются личные формы (Куприна, Матвеева, 2013, с. 276). Тенденция редкого использования конвербов в устной речи по сравнению с письменной очевидна и в литовском языке (0,4\% в субкорпусе устной речи). Тем не менее, и в русской, и в литовской разговорной речи конвербы употребляются, однако часто в качестве компонентов вставных дискурсивных фраз: собственно говоря, честно говоря - tiesq sakant, atvirai kalbant, atvirai pasakius, tiesq pasakius; кстати говоря, грубо говоря, - liaudiškai tariant; мягко говоря švelniai tariant; короче говоря - trumpai tariant; иначе говоря - kitaip sakant, kitaip tariant; kaip sakant, taip sakant 'так сказать'; pagalvojus 'если подумать'. Конвербы такого рода составляют 36\% употреблений в устном субкорпусе НКРЯ и 28\% в устном субкорпусе DLKT.

\section{Заключение}

В данной работе мы рассмотрели аспекты грамматики и употребления русских и литовских конвербов. Некоторые из этих аспектов продолжают оставаться в поле зрения лингвистов, периодически пересматриваются и получают новые интерпретации, как, например, вопросы происхождения конвербов (Пичхадзе, 2016) или нормы их употребления (Онипенко, Биккулова, 2016).

Однако, с нашей точки зрения, наиболее актуальным вопросом сопоставления конвербов в русском и литовском языках остается взаимодействие видовых и акциональных свойств конверба и опорного глагола при реализации семантики отношения между выражаемыми действиями.

Относительно-временные (таксисные) значения в русских и литовских предложениях с конвербами реализуются по-разному: в русском языке - за счет коррелирующих видовых пар деепричастий, в литовском - за счет коррелирующих форм конвербов настоящего и прошедшего времени. Между данными типами корреляций предполагается соответствие: деепричастию НСВ соответствуют литовские конвербы настоящего времени, деепричастию СВ - литовские конвербы прошедшего времени.

Тем не менее предпринятый нами анализ материалов корпусов НKРЯ и DLKT выявляет контексты, в которых проявляются закономерности другого характера. В частности, в контекстах интерпретативно-оценочного действия русским деепричастиям СВ в литовском языке соответствуют не причастия прошедшего времени, а полупричастия СВ. Можно выделить следующие типы контекстов: способ осуществления действия, случайное физическое следствие, целенаправленный результат, логическое следствие или оценка действия.

Из этого следует, что закономерности употребления конвербов не сводятся к списку устойчивых грамматических корреляций и требуют широкого анализа проекций контекстов с учетом их функционально-стилевых разновидностей.

Сопоставительные исследования сущностных характеристик видо-временных категорий русских и литовских глаголов, функционального распределения финитных и нефинитных глагольных форм, в частности форм конвербов в каждом из анализируемых языков, имеют не только теоретическую, но и очевидную практическую значимость. Подобные исследования способствуют решению актуальных прикладных задач, связанных с разработкой материалов для чтения академических курсов, посвященных этноязыковым аспектам мировидения, для преподавания рассматриваемых языков в качестве иностранных, а также с теорией и практикой двуязычного перевода текстов различных стилей. 
Сокращения

Литература
1/2/3 - лицо, ACC - аккузатив, CNV - конверб, DAT - датив, F - женский род, GEN генитив, INF - инфинитив, M - мужской род, NOM - номинатив, PART - причастие, PL - множественное число, PRS - настоящее время, PST - прошедшее время, SG единственное число.

1 Абдулхакова, Л. Р. (2007). Из истории русского деепричастия [From the history of Russian dejeprichastije]. Казань: Казан. гос. $\mathrm{yH}-\mathrm{T}$.

2 Акимова, Т. Г., Козинцева, Н. А., (1987). Зависимый таксис [Dependent taxis]. In A. B. Бондарко (Ред.), Теория функциональной грамматики. Введение. Аспектуальность. Временная локализованность. Таксис [Theory of functional grammar. Introduction. Aspectuality. Temporal Iocalization. Taxis] (сс. 257-274), Ленинград: Наука.

3 Амбразас, В. (1990). Сравнительный синтаксис причастий балтийских языков [Comparative syntax of Baltic languages]. Vilnius: Mokslas.

4 Амбразас, В. (Ред.). (1985). Грамматика литовского языка [Lithuanian grammar]. Вильнюс: Мокслас.

5 Анисимова, Е. В. (2000). Употребление деепричастий совершенного вида в современной русской речи (в прозаических художественных и публицистических текстах) [Usage or perfective converbs in modern Russian (in fiction and publicistic prose texts)] (автореферат дисс, НГУ им. Н.И. Лобачевского). Нижний Новгород: НГУ им. Н.И. Лобачевского.

6 Аркадьев, П. М. (2008). Уроки литовского языка для славянской аспектологии [Lessons of Lithuanian for the Slavic aspectology]. In A. М. Молдован (Ред.) Славянское языкознание. XIV международный съезд славистов (Охрид, 10-16 сентября 2008 г.). Доклады российской делегации [Slavic linguistics: Russian Contributions to the XIV International Congress of Slavists (Ohrid, 10-16.09.2008)] (сс. 28-43). Москва: Индрик.

7 Аркадьев, П. М. (2009). Теория акциональности и литовский глагол [Theory of actionality and Lithuaninan verb]. Балто-славянские исследования, 18, 72-94.
8 Аркадьев, П. М. (2011). Проблемы синтаксиса конструкций «accusativus cum participio» в литовском языке [Problems in synatax of accusativus cum participio construction in Lithuanian]. In Вопросы языкознания, 5, 44-75.

9 Аркадьев, П. М. (2012). Аспектуальная система литовского языка (с привлечением ареальных данных) [Aspectual system of Lithuanian (with areal data)]. Acta Linguistica Petropolitana, 8 (2), 45-121.

10 Аркадьев, П. М. (2016). (Не)согласование причастий и два типа конструкций с неноминативными субъектами в литовском языке [Non-agrement of participles and two types of constructions with nonnominative subjects in Lithuanian]. In A.B. Циммерлинг, Е. А. Лютикова (Ред.), Архитектура клаузы в параметрических моделях: синтаксис, информационная структура, порядок слов (сс. 394-416). Москва: Языки славянских культур.

11 Биккулова, О. С. (2011). Деепричастие [Deeprichastie]. Материалы для проекта корпусного описания русской грамматики. http://rusgram.ru

12 Бондарко, А. В. (1987а). Замечания об отношениях недифференцированного типа [Remarks on non-differential type or relations]. In A. В. Бондарко (Ред.), Теория функциональной грамматики. Введение. Аспектуальность. Временная локализованность. Таксис [Theory of functional grammar. Introduction. Aspectuality. Temporal localization. Taxis] (cc. 253-256). Ленинград: Наука.

13 Бондарко, А. В. (1987б). Общая характеристика семантики и структуры поля таксиса [General characteristics of the semantics and the structure of the field of taxis category]. In А. В. Бондарко (Ред.), Теория функциональной грамматики. Введение. Аспектуальность. Времен- 
ная локализованность. Таксис [Theory of functional grammar. Introduction. Aspectuality. Temporal localization. Taxis] (сс. 234-242). Ленинград: Наука.

14 Борковский, В.И.Кузнецов, П. С. (1963/2006). Историческая грамматика русского языка [Historical grammar of Russian]. Москва.

15 Букатевич, Н.И., Савицкая, С. А., Усачева, Л. Я. (1974). Историческая грамматика русского языка [Historical grammar of Russian]. Киев: Вища школа.

16 Валгина, Н. С. (Ред.). 2002. Современный русский язык [Contemporary Russian]. Moсква: Логос.

17 Вимер, Б. (2001). Аспектуальные парадигмы и лексическое значение русских и литовских глаголов [Aspectual paradigm and lexical meanings of Russian and Lithuanian verbs]. Вопросы языкознания, 2, 26-58.

18 Вимер, Б. (2004). Таксис и коинциденция в зависимых предикациях: литовские причастия на -damas [Taxis and coincidence in subordinated predications: Lithuanian -damas participles]. In В. С. Храковский и др. (Ред.) 40 лет Санкт-Петербургской типологической школе [40 years of St. Petersburg typology group] (cc. 197-240). Москва: Знак.

19 Вимер, Б. (2009). Таксис в литовском языке [Taxis in Lithuanian]. In В. С. Храковский (Ред.), Типология таксисных конструкций [Typology of taxis constructions] (cс. 161216). Москва: Знак.

20 Виноградов, В. В., Истрина, Е. С. (Ред.). 1954 (1960). Грамматика русского языка. Том II. Синтаксис. 41 [Russian grammar. Vol. 1. Phonetics and Morphology]. Москва: $\mathrm{AH} \mathrm{CCCP}$

21 Виноградов, В. В., Истрина, Е. С., Бархударов, С. Г. (Ред.). (1954/1960). Грамматика русского языка. Том І. Фонетика и морфология [Russian grammar. Vol. 2. Syntax. Part 1]. Москва: АН СССР.

22 Вишняускене, Д.М.(2008). Перевод конструкций с деепричастиями на литовский язык в научной речи [Translation of converb constructions into Lithuanian in science discourse]. Studies about Languages, 12, 36-43.

23 Вяткина, С.В.(Ред.). (2009). Синтаксис современного русского языка [Syntax of contemporary Russian]. Москва: Академия.

24 Галнайтите, Э. (1963). Особенности категории вида глаголов в литовском языке (в сопоставлении с русским языком). Kalbotyra, 7, 123-144.

25 Генюшене, Э. (2014). Конвербы в литовском языке [Converbs in Lithuanian]. Acta Linguistica Petropolitana, 10 (3), 157-180.

26 Гловинская, М. Я. (1996/2000). Активные процессы в грамматике [Active processes in grammar]. In: E. А. Земская (Ред.), Русский язык конца XX столетия (1985-1995) [Russian language in the end of $X X$ th century (1985-1995)] (сс. 237-304). Moсква: Языки русской культуры.

27 Добрушина, Е. Р. (2009). Видев и увидя: жизнь и смерть нестандартных деепричастий [,Videv'and ,uvidja': the life and death of non-standart converbs]. In K. Kuceлёва (Ред.), Корпусные исследования по русской грамматике (сс. 15-33). Москва: Пробел.

28 Живов, В. М. (2012). О времени о обстоятельствах появления несогласованных кратких действительных причастий (деепричастий) в языке русской письменности [On time and circumstances of the bearth of non-agreeing short participles (converbs) in written Russian]. In М.Д. Воейкова (Ред.), От значения к форме, от формы к значению (сс. 179-189). Москва: Языки славянской культуры.

29 Зализняк, А. А. (2004). Древненовгородский диалект [Old Novgorod dialect]. Moсква: Языки славянской культуры.

30 Земская, Е. А. (Ред.). (1973). Русская разговорная речь [Russian spoken discourse]. Москва: Наука.

31 Йокояма, О., (1983). В защиту запретных деепричастий. In M. S. Flier (Ed.), American Contributions to the Ninth International Congress of Slavists (Kiev, September 1983), 
Vol. 1 Linguistics, (pp. 373-81). Columbus, Ohio: Slavica.

32 Ицкович, В. А. (1982). Очерки синтаксической нормы [Essays on the norm in syntax]. Москва: Наука.

33 Кибрик, А. А., Подлесская, В. И. (Ред.). (2009). Рассказы о сновидениях [Stories about dreams]. Москва: Языки славянской культуры.

34 Ковальская, В. М. (2016). Параметры словообразовательной конверсии и русские деепричастия [Parameters of word-formation conversion and Russian converbs]. Rhema. Ремa, 4, 43-57.

35 Ковтунова, И. И. (1964). Изменения в системе сложного предложения [Changes in the system of compound sentence]. In В. В. Виноградов, Н. Ю. Шведова (Ред.), Очерки по исторической грамматике русского литературного языка XIX века [Essays on grammar of Russian literary language in XIXth century] (cc. 369-482). Москва: Наука.

36 Купина, Н. А., Матвеева, Т. В. (2013). Стилистика современного русского языка [Modern Russian stylistics]. Москва: Юрайт.

37 Маслов, Ю.С. (2004). Избранные труды [Selected writings]. Москва: Языки славянской культуры.

38 Муравьев, Н. А. (2017). Таксис и таксисные формы в языках мира: таксономия и типология [Taxis and its forms in the languages of the world: taxonomy and typology] (диссертация, Московский государственный университет имени М. В. Ломоносова). Москва: МГУ.

39 Мустейкис,К. (1972). Сопоставительная морфология русского и литовского языков [Comparative grammar of Russian and Lithuanian], Вильнюс: Минтис.

40 Мустейкис, К. (2012). Функциональная грамматика русского и литовского языков [Functional grammar or Russian and Lithuanian]. Вильнюс: Эдукология.

41 Недялков, И. В. (2003). Зависимый таксис в разноструктурных языках: значе- ние одновременности / предшествования / следования [Dependent taxis in the languages of different structures: meanings of simultaneity, precedence and concession]. In A. В. Бондарко (Ред.) Проблемы функциональной грамматики: семантическая инвариантность / вариативность [Problems of functional grammar: semantic invariance / variation] (cc. 156174). Санкт-Петербург: Наука.

42 Онипенко, Н. К., Биккулова, О. С., 2016. Проблема деепричастной нормы и категория субъекта [The problem of the norm of the usage of converbs and the category of subject]. In Труды института русского языка им. В.В. Виноградова, 10, 218-229.

43 Пешковский, А. М. (1956/2001). Русский синтаксис в научном освещении [Russian syntax in scientific coverage]. Москва: Языки славянской культуры.

44 Пичхадзе, А. А. (2016). О предикативном vs. атрибутивном употреблении причастий в древнерусском. неизменяемые категори [On predicative vs. attributive usage of participles in Old Russian: nonagreeing participles]. In Труды института русского языка им. В.В. Виноградова, 10, 444-516.

45 Полянский, С. М. (1987). Одновременность/разновременность и другие типы таксисных отношений [Simultaneity / non-simultaneity and other types of taxis relations]. In A. В. Бондарко (Ред.), Теория функциональной грамматики. Введение. Аспектуальность. Временная локализованность. Таксис [Theory of functional grammar. Introduction. Aspectuality. Temporal localization. Taxis] (cc. 243-253). Ленинград: Наука.

46 Потебня, А. А. (1889/1958). Из записок по русской грамматике. Том 1-2 [Form notes on Russian grammar. Vol. 1-2]. Москва: Гос. учебно-педагогическое изд. Министерства просвещения РСФСР.

47 Розенталь, Д. Э., Джанджакова, Е. В., Кабанов, Н. П. (1998). Справочник по правописанию, произношению, литературному редактированию [Guide on spelling, 
pronunciation, literary editing]. Москва: ЧePo.

48 Храковский, В. С. (2009). Таксис: Семантика, синтаксис, типология [Taxis: semantics, syntax, typology]. In В. С. Храковский (Ред.), Типология таксисных конструкций [Typology of taxis constructions] (сс. 11-113). Москва: Знак.

49 Шахматов, А. А. (1941/2001). Синтаксис русского языка [Russian syntax]. Москва: УPCC.

50 Шведова, Н. Ю. (Ред.). (1980а). Русская грамматика. Т. 1 [Russian grammar. Vol. 1]. москва: Наука.

51 Шведова, Н. Ю. (Ред.). (19806). Русская грамматика. T. 2 [Russian grammar. Vol. 2]. Москва: Наука.

52 Шведова, Н.Ю.(Ред.). (1970). Грамматика русского литературного языка [The grammar of Russian literary language]. Moсква: Наука.

53 Шмелева, Т. В. (1984). Деепричастия на службе у модуса [Converbs in service with modus]. In В. А. Белошапкова (Ред.) Системный анализ значимых единиц русского языка. Синтаксические структуры [Systemic analysis of meaningful items of Russian. Structures in syntax] (cc. 64-70) Красноярск: КГУ.

54 Якобсон, Р. (1972). Шифтеры, глагольные категории и русский глагол [Shifters, verbal categories and the Russian verb]. In Б. А. Успенский (Ред.), Принципы типологического анализа языков различного строя [Principles of the typological analysis of languages with different structures] (cc. 95-113). Москва: Наука.

55 Ambrazas, V. (Ed.). (1997). Lithuanian grammar. Vilnius: Baltos lankos.

56 Ambrazas, V. (Red.). (2005). Dabartinès lietuvių kalbos gramatika. Vilnius: Mokslo ir enciklopedijų leidybos institutas.

57 Ambrazas, V. (1962). Absoliutinis naudininkas XVI - XVII a. lietuvių kalbos paminkluose. Lietuvių kalbotyros klausimai, 5, 5-146.

58 Ambrazas, V. (2006). Lietuvių kalbos istorinè sintaksè. Vilnius: Lietuvių kalbos institutas.

59 Birzer, S. (2010). Русское деепричастие. Процессы грамматикализации и лексикализации. Munchen: Verlag Otto Sagner.

60 Brazauskienè, J., Miškinienè, I. (2007). Neasmenuojamosios veiksmažodžio formos - vertimo rifai. Kalbotyra, 57 (3), 4045.https://doi.org/10.15388/KIbt.2007.7556

61 Haspelmath, M. (1995). The converb as a cross-linguistically valid category. In M. Haspelmath, and E. König, (Eds.) Converbs in Cross-Linguistic Perspective. Structure and Meaning of Adverbial Verb Forms Adverbial Participles, Gerunds (pp. 1-55). Berlin, New York: Mouton de Gruyter. https://doi.org/10.1515/9783110884463-003

62 Haspelmath, M. (1999). Converb. In K. Brown, K., J. Miller (Eds), Concise encyclopedia of grammatical categories (pp. 110-114). Kidlington: Elsevier.

63 Ylikoski, J. (2003). Defining Non-finites: Action Nominals, Converbs and Infinitives. SKY Journal of Linguistics, 16, 185-237.

64 Nedjalkov, V. I. (1995). Some typological parameters of converbs. In M. Haspelmath, and E. König, (Eds.) Converbs in CrossLinguistic Perspective. Structure and Meaning of Adverbial Verb Forms Adverbial Participles, Gerunds (pp. 97-136). Berlin, New York: Mouton de Gruyter. https:// doi.org/10.1515/9783110884463-005

65 Nedjalkov, V. I., Nedjalkov, I. V, 1987. On the typological characteristics of converbs. In: T. Help, (Ed.), Symposium on Language Universals (Tallinn, July 29-30, 1987). (pp. 75-79) Tallinn: Academy of Sciences of the Estonian S.S.R.

66 Paulauskienè, A. (1979). Gramatinès lietuviụ kalbos veiksmažodžio kategorijos. Vilnius: Mokslas.

67 Rimkutè, E., (2006). Dabartinès lietuvių kalbos gramatinių formų vartosena morfologiškai anotuotame tekstyne. Lituanistica, 66 (2), 34-55.

68 Rheuther, T. (2011). Interpretative Verbs and Interpretative Constructions with Converb Clauses. Proceedings of the 5th 
International Conference on Meaning-Text Theory, Barcelona, September 8 - 9, 2011 (pp. 232-242).

69 Ulvydas, K. (Red.). (1971). Lietuvių kalbos gramatika. II t. Vilnius: Mintis.

70 Ulvydas, K. (Red.). (1976). Lietuvių kalbos gramatika. III t. Vilnius: Mintis.

71 Usonienè, A., Vincent, N. (2018). Nonfiniteness, complementation and evidentiality: The Lithuanian Accusativus cum Participio in a cross-linguistic perspective. In D. Ayoun, A. Celle, A , Lansari (Eds.), Tense, Aspect, Modality,

НКРЯ - Национальный корпус русского Источники языка (доступ: http://www.ruscorpora.ru/ new/)

РГ - Русская грамматика

РКГ - Русская корпусная грамматика

DLKG - Dabartinès lietuvių kalbos gramatikа (Грамматика современного литовского языка) and Evidentiality (Studies in Language Companion Series, No. 197) (pp. 239-260) Amsterdam: John Benjamins.https://doi. org/10.1075/slcs.197.11uso

72 van der Auwera, J. (1998). Defining converbs. In L. Kulikov, H. Vater (Eds.), Typology of Verbal Categories: Papers Presented to Vladimir Nedjalkov on the Occasion of his 70th Birthday (pp. 273282), Tübingen: Max Niemeyer Verlag. https://doi.org/10.1515/9783110913750.273

73 Vyšniauskienè, D., Kravcova, L. (2018). Mokslinio techninio teksto vertimo ypatumai. Kaunas: Technologija.

DLKT - Dabartinés lietuvių kalbos tekstynas (Корпус современного литовского языка, доступ: http://tekstynas.vdu.lt/tekstynas/, аннотированный подкорпус: http:// corpus.vdu.lt/lt/ )

LKG - Lietuvių kalbos gramatika (Грамматика литовского языка)

\section{Santrauka}

\section{Diana Burbienè, Ala Lichačiova. Konverbai rusų ir lietuviụ kalbose}

Šiame darbe pristatoma rusụ ir lietuvių kalbụ konverbu savybių gretinamoji apžvalga. Straipsnyje apibendrinami žinomi duomenys apie šių veiksmažodžio formų kilmę, vartojimą šiuolaikinėse rusụ ir lietuviụ kalbose, ju sintaksines funkcijas. Konverbai gretinami veiksmažodžio gramatiniụ kategoriju, taip pat veikiančiojo subjekto žyméjimo atžvilgiais.

Pagrindine konverbụ semantine savybe laikomas jais žymimo veiksmo santykis su pagrindiniu veiksmažodžiu reiškiamu veiksmu, dèl kurio konverbai lokalizuoja i̇vykius laiko ašyje pagrindinio veiksmažodžio deiktinès laiko reikšmés kontekste. Šiuo požiưriu konverbai atstovauja priklausomo taksio (santykinio laiko) kategorijai, kurio reikšmes (vienalaikiškumas / ankstesnumas) rusụ ir lietuviụ kalbose realizuojamos skirtingai: rusų kalboje tam tarnauja veikslo opozicijos žymejjimas, lietuvių kalboje - laikụ opozicijos žyméjimas.

Nacionalinio rusų kalbos tekstyno (HKPЯ) ir DLKT duomenų analizè rodo, jog konverbụ koreliacijų atitikmenys (eigos dejepričiastije - pusdalyvis, ivykio dejepričiastije - veikiamasis būtojo laiko dalyvis) funkcionuoja daugelyje laiko santykio kontekstų, tačiau loginio santykio kontekstuose veikia kitokio pobūdžio dèsningumai.

\section{Summary}

\section{Diana Burbienè, Ala Lichačiova. Converbs in Russian and Lithuanian}

The paper gives a comparative overlook on peculiarities of Russian and Lithuanian converbs. Origins, modern usage of the forms and syntactic functions of converbs are summarized. Converbs are compared in regard of marking of verbal categories and relation to the subject of an action of a main verb. It is emphasized that the main semantic feature of these verb forms is a connection of an action referred by a converb to the action referred by verb, whereby converbs localize events on the time axis in the context of a deictic value of a main verb. From this point of view, converbs are a kind of dependent taxis where meanings (simultaneity / anteriority) have different morphological realization in Russian and Lithuanian: in Rus- 
sian by means of the opposition of the lexical aspect markers, and in Lithuanian by means of the opposition of the tense markers. On the grounds of the analysis of corpora materials (RNC and CCLL), it is shown that equivalence between correlative forms (Russian imperfective converb - Lithuanian half-participle / non-agreeing present participle, Russian perfective converb - Lithuanian active past participle / non-agreeing past participle) is relevant in most instances of the contexts of a temporal relation, but in the contexts of logical relation there are regularities of dissimilar nature.

Об авторах

\section{ДИАНА БУРБЕНЕ}

Докторант Института языков, литературы и перевода, Вильнюсский университет, лектор Института социальных, гуманитарных наук и искусств, Каунасский технологический университет, Литва

\section{Области научных интересов}

Сопоставительные исследования по русскому и литовскому языку, язык медиа, корпусная лингвистика.

\section{Адрес}

ул. А. Мицкевича 37, лТ-44249, Каунас, Литва

Эл. почта diana.burbiene@ktu.lt

ORCID: 0000-0002-8435-090X

\section{АЛЛА ЛИХАЧЕВА}

Д-р гуманитарных наук, профессор кафедры русской филологии, Вильнюсский университет, Литва

Области научных интересов

Звучащая русская речь, связи языка и культуры, социолингвистика, сопоставительные исследования по русскому и литовскому коммуникативному поведению.

\section{Адрес}

ул. Университето 5, лТ-01513, Вильнюс, Литва

Эл. почта ala.lichaciova@flf.vu.lt

ORCID: 0000-0002-8768-7815 